URL: https://www.kmu.gov.ua/storage/app/media/reforms/ukrainska-shkola-compressed.pdf (data zvernennia: 10.09.2021). [in Ukrainian].

Derzhavnyi standart bazovoi serednoi osvity vid 30.09.2020 r. № 898 [State standard of basic secondary education. Resolution of the Cabinet of Ministers of Ukraine]. URL: https://www.kmu.gov.ua/npas/pro-deyaki-pitannya-derzhavnih-standartiv-povnoyi-zagalnoyi-serednoyi-osviti-i300920-898 (data zvernennia: 15.09.2021). [in Ukrainian].

Horak, O. P. (2015). Osoblyvosti formuvannia hotovnosti do zdiisnennia moralnoho vyboru u problemnykh sytuatsiiakh: emotsiino-tsinnisnyi komponent [State standard of basic secondary education. Resolution of the Cabinet of Ministers of Ukraine]. Molodyi vchenyi. № 12. Ch. 3. S. 121-124. [in Ukrainian].
Tymoshchuk, I. V. (2005). Pedahohichni umovy vykhovannia u studentiv medychnoho tekhnikumu humanistychnykh tsinnostei [Pedagogical conditions of education of students of medical technical school of humanistic values]: avtoref. dys... kand. ped. nauk. Ternopil: Ternop. nats. ped. un-t im. V. Hnatiuka. 20 s. [in Ukrainian].

Smahina T. M. Teoretychni ta praktychni osnovy konstruiuvannia kompetentnisnoho uroku [Theoretical and practical bases of constructing a competence lesson]. (2012). Visnyk Zhytomyrskoho derzhavnoho universytetu imeni Ivana Franka. Vyp. 61. S. 128-131. URL: http:// nbuv.gov.ua/UJRN/VZhDU_2012_61_26 [in Ukrainian].

Дата надходження до редакиіï: 05.11.2021 p.
УДК [811.161.2:378.016.]:008

DOI: $10.37026 / 2520-6427-2021-108-4-91-98$
Наталія МУШИРОВСБКА, кандидат філологічних наук, доцент кафедри стилістики та культури украӥнської мови Рівненського державного гуманітарного університету, м. Рівне, Украӥна ORCID: 0000-0003-1319-1101 e-mail: nat.mushyrovska@gmail.com

\title{
УКРАЇНОЗНАВЧІ ЗАСАДИ ВИКЛАДАННЯ УКРАЇНСЬКОЇ МОВИ ЗА ПРОФЕСІЙНИМ СПРЯМУВАННЯМ СТУДЕНТАМ СПЕЦІАЛЬНОСТІ «КУЛЬТУРОЛОГІЯ»
}

Анотація. Стаття присвячена проблемі організації мовної професійної підготовки фахівців-культурологів на засадах українознавства на заняттях з украӥнської мови за професійним спрямуванням. У ній здійснена спроба намітити основні шляхи реалізаціі украӥнознавчого підходу для формування мовно-професійних компетентностей здобувачів вищої освіти за фахом «Культурологія», означено роль принципів міжпредметності та текстоиентризму у його застосуванні, щзо передбачає поліфункиіональне використання текстів українознавчої тематики, з'ясовано дидактичні можливості використання украӥнознавчого матеріалу на заняттях з украӥнської мови за професійним спрямуванням, запропоновано можливі види завдань для роботи з текстом украӥнознавчої, соиіокультурної тематики.

У публікаиії розглянуто змістове наповнення дисичилліни в контексті концепиій мовної освіти, завданням яких є розробити технологію формування національно свідомої україномовної особистості, компетентної у низиі аспектів: мовному, мовленнєвому, стратегічному, сочіокультурному, украӥнознавчому. Проаналізовано значимість українознавчого змісту у навчальних матеріалах та підручниках з украӥнської мови за професійним спрямуванням. Звернено увагу на необхідність залучення фактів з історії української мови і культури до освітнього контенту з метою формування мовної $і$ мовленнєвої компетентності, культури мови, виховання історичної пам'яті, національної свідомості і мовної стійкості. Зокрема, в результаті змістового та мовного аналізу украйнознавчого тексту фахівці поглиблюють свої знання інформацією культурологічного змісту, більш глибоко засвоюють національно-культурні компоненти мови, збагачують свій словниковий запас спеціальними лексико-граматичними одинииями. Украӥнознавчий текстовий матеріал мотивує створювати власні тексти культурологічного спрямування, висловлюватися, викладати своє бачення інформаиії, вступати в дискусію. Моделювання професійних комунікативних ситуацій сприяє набуттю досвіду мовленнєвої діяльності, готовності до ситуативного мовлення, успішної реалізачії комунікативного наміру у професійній діяльності.

Ключові слова: мовна особистість, мовленнєві вміння й навички, міжпредметні зв'язки, етнолінгвістичний підхід, текстоцентричний підхід, лексикосемантичний підхід. 
Nataliia MUSHYROVSKA,

PhD in Philology, Associate Professor,

Department of Stylistics and Culture

of the Ukrainian Language,

Rivne State Humanitarian University,

Rivne, Ukraine

ORCID: 0000-0003-1319-1101

e-mail: nat.mushyrovska@gmail.com

\section{UKRAINIAN STUDIES PRINCIPLES OF TEACHING THE UKRAINIAN LANGUAGE FOR PROFESSIONAL PURPOSES TO STUDENTS OF SPECIALITY «CULTUROLOGY»}

\begin{abstract}
The article is devoted to the problem of organization language professional training of culturologists on the basis of Ukrainian studies in classes of Ukrainian language for professional purposes. It attempts to outline the main ways to implementatiom the Ukrainian studies approach for the formation of professional language competencies of students in the specialty "Culturology», indicated the role of the principles of intersubjectivity and text-centrism in its application, which provides for the multifunctional use of texts on Ukrainian studies, the didactic possibilities of using Ukrainian studies material in classes of Ukrainian language for professional purposes are clarified, possible types of tasks for working with the text of Ukrainian studies and socio-cultural topics are suggested.
\end{abstract}

The article considers the content of the discipline in the context of the concepts of language education, which aims to develop technology for the formation of nationally conscious Ukrainian-speaking personality, competent in a number of aspects: language, speech, strategic, sociocultural, Ukrainian studies, analyzes the importance of Ukrainian studies content in educational materials and textbooks on the Ukrainian language for professional purposes. Attention is drawn to the need to involve facts from the history of the Ukrainian language and culture in educational content for the formation of language and speech competence, speech culture, education of historical memory, national consciousness and language stability.

In particular, as a result of semantic and linguistic analysis of Ukrainian studies texts, specialists deepen their knowledge with information of culturological content, learn more deeply the national and cultural components of the language, enrich their vocabulary with special lexical and grammatical units. Ukrainian studies text material motivates to create their own texts of cultural orientation, to speak, to express their vision of information, to enter into a discussion. Modeling of professional communicative situations contributes to the acquisition of experience of speech activity, readiness for situational speech, successful realization of communicative intention in professional activity.

Key words: linguistic personality, speech skills, interdisciplinary connections, ethnolinguistic approach, text-centered approach, lexical-semantic approach.

Постановка проблеми. Мовна підготовка здобувачів вищої освіти підпорядкована загальним вимогам сьогодення і формується у контексті сучасної методичної науки, завданням якої є формування мовної особистості, яка вільно і досконало володіє мовою, зокрема мовою професійного спілкування (усною і писемною), здатної до індивідуальної мовотворчості. Показником належного володіння мовою є достатній обсяг активного словника, володіння спеціальною лексикою і термінологією, різноманітність використовуваних граматичних форм і конструкцій, уміння добирати мовний матеріал відповідно до умов та ситуації професійного спілкування, що забезпечує уміння вільного самовираження мовної особистості у професійній сфері.

Використання матеріалів українознавчого характеру є центральним принципом навчання української мови у контексті професійної підготовки студентів спеціальності 034 «Культурологія», формування у них теоретичних і практичних компетентностей, «необхідних для здійснення освітньої та соціокультурної діяльності, а також оволодіння науковими методами та інноваційними технологіями у сфері культури для вирішення завдань культурної політики держави», про що йдеться в освітній програмі спеціальності (Освітньо-професійна програма «Культурологія», 2019, с. 4).

Це зумовлює потребу викладання української мови за професійним спрямуванням студентам-культурологам на якісно новому рівні, із застосуванням міжпредметних зв'язків із фаховими дисциплінами, такими як історія України, історія мистецтв, українська культура, історіографія культури України, народна художня культура, соціокультурне проєктування, культурологія дозвілля, музеєзнавство (Освітньо-професійна програма «Культурологія», 2019, С.11), що формують змістову орієнтацію вивчення української мови, дають необхідний матеріал та можливість взаємодоповнення дисциплін.

Аналіз наукових досліджень і публікацій. Культурознавчі підходи до вивчення української мови висвітлювалися в контексті етнопедагогіки, етнопсихолінгвістики, лінгвокультурології та лінгвокраїнознавства. Етнопедагогічні основи навчання української мови аналізуються у працях М. Г. Стельмаховича, Н. Д. Бабич, С. Я. Єрмоленко, В. І. Кононенка, Л. І. Мацько, М. І. Пентилюк, Т. В. Симоненко, О. Є. Смолінської, О. М. Семеног, О. Н. Хорошковської, В. В. Шляхової. Вплив етнопсихологічних чинників на формування мовної особистості відображені у роботах А. Р. Лурії, І. А. Зимньої, Ю. М. Караулова, 
Ю. О. Сорокіна та ін. Про актуальність міжпредметних зв'язків зазначали О. Біляєв, В. Мельничайко, М. Пентилюк, Г. Передрій, В. Ужченко, Т. Груба та інші, які наголошували на необхідності системної міжпредметної роботи, яка призводить до підвищення науковості й доступності навчання української мови, посилення пізнавальності, покращення якості знань і навичок. Проте застосування українознавчого підходу, що грунтується на міжпредметних зв’язках, у практиці професійної підготовки майбутніх культурологів у вищій школі ще не знайшло достатнього висвітлення і потребує більш детального розгляду й узагальнень.

Метою статті $є$ дослідження проблеми організації мовної професійної підготовки майбутніх фахівців-культурологів на засадах українознавства, дослідження ролі міжпредметного підходу у процесі формування їхньої мовної компетенції та комунікативних навичок на заняттях з української мови за професійним спрямуванням, представленості українознавчого змісту у навчальних матеріалах.

Завдання дослідження - намітити основні шляхи реалізації українознавчого підходу у вивченні української мови в поєднанні мовної і культурної складової як одного з ефективних методів формування професійних компетентностей здобувачів вищої освіти за фахом «Культурологія». Для досягнення зазначених мети i завдань слід з'ясувати дидактичні можливості використання міжпредметного (українознавчого) матеріалу на заняттях з української мови за професійним спрямуванням, запропонувати можливі види завдань для роботи з текстом українознавчої, соціокультурної тематики, що сприятимуть формуванню мовно-комунікативної професійної компетентності фахівців-культурологів.

Виклад основного матеріалу дослідження. Програмний зміст дисципліни «Українська мова (за професійним спрямуванням)» передбачає оволодіння мовою професії з усвідомленням комунікативної ситуації професійного спілкування, іiі змісту, мети, учасників, обставин спілкування. Згідно з освітньо-професійною програмою спеціальності 034 «Культурологія», об'єктом вивчення здобувачів вищої освіти є «ключові поняття, методологічний інструментарій та концепції теорії, icторії культури, базові дефініції культурних практик; значення та смисли феноменів культури і культурних процесів минулого та сучасності, що представлені в артефактах, текстах і соціокультурних практиках; соціокультурні інституції мистецького, освітнього, наукового, морального спрямування, що забезпечують формування культурних норм та цінностей». Цілями навчання $€$ «опанування фундаментальними основами культурології; оволодіння теоретико-методологічними засадами дослідження культурно-історичної динаміки та різних форм культури; набуття навичок розуміння соціокультурних процесів у суспільстві загалом та спеціалізованих інститутах зокрема» (Освітньо-професійна програма «Культурологія», 2019, с. 5). Здобувачі вищої освіти можуть працювати викладачами професійного навчального закладу, організаторами позакласної та позашкільної роботи з дітьми, керівниками студій за видами мистецтва та художньої творчості, любительських об'єднань, клубів за інтересами (Освітньо-професійна програма «Культурологія», 2019, с. 5-6).
У результаті опанування освітньої програми у студентів-культурологів мають бути сформовані такі загальні компетентності, як здатність до аналізу та синтезу, до застосування знань у практичних ситуаціях, знання предмета та розуміння професійної діяльності, професійне володіння (усне та письмове) державною мовою, здатність генерувати нові ідеї (креативність), здатність до пошуку, оброблення та аналізу інформації, дослідження різних типів культурних практик, здатність діяти на основі етичних міркувань соціально відповідально та свідомо. Професійними компетентностями є осмислення теоретичних концепцій і вчень, які становлять основу культурології, здатність використовувати загальні й спеціальні методи та інструменти дослідження проблем культурології, застосовувати термінологічний апарат культурології, розуміти процеси культурно-історичної динаміки, налагоджувати комунікативний процес із представниками різних соціально-культурних угруповань у процесі підготовки та організації культурно-дозвіллєвої діяльності та соціокультурного проєктування, вміння орієнтуватися в етапах розвитку художньої культури та видах мистецтва, розробляти та регулювати інноваційні соціокультурні та мистецькі проєкти, здатність використовувати знання з основ наукових досліджень як складової культурологічної освіти та наукової творчості (Освітньо-професійна програма «Культурологія», 2019, с. 8-7).

Означені завдання професійної підготовки дають поштовх до осмислення українознавчих засад викладання мови за професійним спрямуванням, змісту цього курсу і навчальних форм у підготовці культурологів, створення підручників і навчальних посібників на українознавчих засадах, втілюючи навчально-дидактичний принцип реалізації міжпредметних зв'язків.

Педагогічна наука розглядає міжпредметні зв'язки як один із основних дидактичних принципів (системності і послідовності, науковості, доступності, зв'язку теорії з практикою, зв'язку навчання з життям, наочності та ін.). (Пентилюк, 1987). Т. Груба у змісті навчальних предметів виокремлює три види міжпредметного матеріалу: понятійно-термінологічний, що виявляється на рівні тотожних міжмовних (слово, лексичне значення, синоніми, антоніми, омоніми тощо) та суміжних понять (епітет, порівняння, пряме і переносне значення слова та ін.); комунікативно-мовленнєвий, що встановлюється на рівні спілкування з дотриманням норм сучасної літературної мови (правильне вживання слів відповідно до ситуації спілкування); навчально-дидактичний, що виникає між усіма навчальними дисциплінами, зміст яких у вигляді текстів може бути використаний на уроках української мови як ілюстрації до тих чи інших мовних явищ під час створення власних висловлювань (Груба, 1998, с. 17).

У контексті українознавчих засад мовної освіти серед пріоритетів можна визначити: 1) важливість формування мовної особистості з українознавчим світоглядом, знанням споконвічних цінностей українського народу і шанобливого ставлення до них (мові належить чільне місце у системі таких цінностей, в утвердженні державності), усвідомлення потреби вивчення мови i долучення через неї до історії, традицій і звичаїв народу, чому має сприяти українознавче наповнення змісту 
підручників, оволодіння багатством виражальних засобів української мови, мовною картиною світу українців; 2) реалізація у процесі формування україномовної особистості інтегрального підходу до опрацювання мови, літератури, історії, використання біографічних прикладів відомих українських особистостей, аналіз їхнього внеску у розбудову української культури та мови, що допомагає формувати мовні смаки й уподобання, позитивну мотивацію і зацікавленість, пожвавлює різні види мовленнєвої діяльності; 3 ) різноаспектне застосування в освітньому процесі з української мови завдань на добір і аналіз мовних одиниць, конструювання, оцінювання, редагування різностильових та різножанрових текстів, що допоможе послуговуватися мовними скарбами доречно і правильно (Шляхова, 2009, с. 4).

У викладанні української мови за професійним спрямуванням на українознавчих засадах можемо зважати на відомі напрацювання і концепції мовної освіти. Зокрема, одним із перших про необхідність застосовувати у методиці навчання рідної мови відомості українознавства заявив М. Г. Стельмахович у праці «Етнопедагогічні основи методики української мови» (1993). Автори С. Я. Єрмоленко та Л. І. Мацько запропонували Навчально-виховну концепцію вивчення української (державної) мови, згідно з якою в основу викладання української мови має бути покладений світоглядний принцип і вектори, які формують національну ідентичність, дозволяють краще пізнати свою країну, народ, культуру та традиції, усвідомити унікальність української мови через ії походження, історію, розвиток (1994). Етнокультурні засади передбачає Концепція навчання державної мови в школах України Інституту педагогіки НАПН України, авторами якої є О. М. Біляєв, Л. В. Скуратівський, Л. М. Симоненкова, Г. Т Шелехова. Основні аспекти концепції здатні реалізуватися й у вищій школі: автори пропонують їі втілення через добір і укладання системи вартісних текстів, які відображають культурну і мовну спадщину українського народу (Біляєв, Скуратівський, Симоненкова, Шелехова, 1996). Українознавчий підхід у процесі вивчення української мови передбачає також Концепція когнітивної методики навчання української мови М. І. Пентилюк, А. В. Нікітіної, О. М. Горошкіної, що пропонує реалізацію етнокультурологічного принципу на текстовій основі через навчання мови у контексті літератури, історії, мистецтва (Пентилюк, Нікітіна, Горошкіна, 2004).

Згідно з концепцією М. Стельмаховича, засади навчання української мови базуються на принципах народності, історизму, етнічної соціалізації, врахування регіонального й родинного мовного середовища, що реалізується через тексти і матеріали регіонального значення, які наближують навчальний процес до реального життя, сприяють вихованню патріотичних почуттів і придатні для різноаспектного мовного аналізу та редагування (аналіз мовленнєвої поведінки земляків, одиниць діалектного мовлення, текстів місцевих 3МI). В опрацюванні мовного матеріалу культурологічний принцип повинен реалізуватися через використання текстів різних видів і жанрів народної творчості, творів української художньої літератури, через ознайомлення 3 нормами народного мовленнєвого етикету. Історизм, що сприяє формуванню історичної пам'яті, формується завдяки відомостям про історію української мови, української лінгвістики та про персоналії видатних учених-мовознавців. Етнічній соціалізації та вихованню патріотизму сприяє ознайомлення з творами та висловлюваннями видатних людей про велич і красу української мови. Принцип регіонального мовного середовища спонукає застосовувати краєзнавчий матеріал, топоніміку й діалектизми в контексті виражальних засобів української мови. Виховний зміст передбачає застосування дидактичного матеріалу, у якому б висвітлювалися народні риси, традиції та норми християнської моралі (Стельмахович, 1993).

С. Срмоленко (2021) вважає, що в основу формування мовної особистості має бути покладений світоглядний принцип. У концепції С. Єрмоленко та Л. Мацько зазначається, що у навчальному контенті має бути представлений зміст, який дозволяє краще пізнати свою країну, народ, культуру та традиції, усвідомити унікальність рідної мови шляхом осмислення інформації про її походження, історію, подальший розвиток, державний статус української мови, усвідомити себе громадянином України і носієм мови, розширити свою світоглядну базу завдяки матеріалам про місце України у світі, про український етнос, природу, історію, право, культуру, сформувати потребу удосконалювати українську мову та дотримуватися іiі норм (Срмоленко, Мацько, 1994).

О. Біляєв, Л. Скуратівський, Л. Симоненкова та Г. Шелехова, керуючись принципами єдності навчання, виховання і розвитку, передбачають у навчальному змісті три змістові компоненти: лінгвістичний (забезпечує формування мовної і мовленнєвої компетенції), етнокультурознавчий та методологічний. Етнокультурознавчий покликаний формувати культуру мовців шляхом ознайомлення з культурними набутками свого народу, виховання патріотизму та моральності. Здійсненню цих завдань має служити текстоцентричний підхід, згідно з яким слід добирати систему вартісних текстів, використовуючи їх як поліфункціональні одиниці (джерело пізнавальної інформації, зразок досягнення комунікативної мети, засіб активізації життєвого досвіду та реалізації дидактичної проблеми). Текст має опрацьовуватися в етнокультурознавчому аспекті в єдності системи значущих тем (пріоритетними $\epsilon$ тексти українознавчої тематики, що демонструють поліфункціональність рідної мови, ііі світоглядної, культуроакумулюючої, пізнавальної, етичної, естетичної, комунікативної вартостей), а робота 3 ним повинна бути досвідом емоційно-ціннісного ставлення до інформації, поштовхом до власної мовотворчості (Біляєв, Скуратівський, Симоненкова, Шелехова, 1996).

Антропоорієнтована когнітивна методика М. Пентилюк, А. Нікітіної та О. Горошкіної має на меті формувати мовну особистість, спроможну сприймати, зберігати, розвивати і передавати певну інформацію, яка стосується національно-мовної картини світу, що передбачає інтенсифікацію навчального процесу за рахунок текстоцентризму. Оскільки мова є частиною культури, то їі опанування має відбуватися через опрацювання (лінгвістичне, культурологічне, комунікативне) текстів українознавчого змісту - про традиції, 
побут, вірування, мовленнєвий етикет, діячів української культури та науки. Критерії добору текстів актуальність, інформативність, доступність, виховний зміст, дидактична наповненість значущими мовними одиницями. Основні принципи когнітивної методики - етнокультурологічний (реалізується через навчання української мови в контексті української культури) та інтегративності (стимулює поєднання вивчення мови та інших навчальних дисциплін). Через роботу з текстом формується предметна, етнокультурологічна, мовна, прагматична і комунікативна компетентності. Зокрема, етнокультурологічна компетенція реалізується у процесі формування національно-мовної картини світу, вивчення національно маркованих мовних одиниць та одиниць українського мовленнєвого етикету. Стимулювання мовотворчості реалізується через діалогізацію навчального процесу (Пентилюк, Нікітіна, Горошкіна, 2004).

Підручники для вищої школи «Українська мова за професійним спрямуванням» (Шевчук, Клименко, 2013), «Культура фахового мовлення» (Бабич, 2006), «Українська мова професійного спілкування» (Мацюк, Станкевич, 2010) та інші загалом створені з урахуванням цих координат як такі, що покликані формувати орфоепічну, орфографічну, лексичну, граматичну, стилістичну, комунікативну, а також культурологічну й інші компетенції. Реалізація українознавчого принципу в них простежується у низці тем, пов'язаних із походженням та історією української мови, описом ії місця серед слов' янських та неслов'янських мов світу, іiї діалектних різновидів, стилістичного розшарування тощо. Українознавчий підхід необхідний також у межах створюваних методичних посібників та рекомендацій для спеціальності «Культурологія», які б формували уявлення тяглості процесу формування української мови від найдавніших праслов'янських часів до сьогодення, виховували б культуру історичної пам'яті, національно оріснтовану мовну особистість, патріота, здатного до критичного мислення.

Сьогодення України переконує у важливості таких відомостей: треба формувати знання про самостійний неперервний розвиток української мови на праслов'янському грунті, у сім'ї інших слов'янських мов, про генезу української мови у двох формах існування - усній та писемній, які мають свої особливості розвитку, додаючи до навчальних посібників відповідний теоретичний і текстовий матеріал. Для формування об'єктивних і конкретних знань з історії становлення української мови однією з необхідних для ознайомлення $є$ хронологія історичного розвитку мови Юрія Шевельова (Мацюк, Станкевич, 2010). Доречними є згадки про пам'ятки староукраїнського письма («Слово про похід Ігорів», «Повість минулих літ»), про потужну староукраїнську літературно-писемну традицію, коли українська мова обслуговувала не лише сферу красного письменства, а й сферу релігії (сприяти зацікавленню студентів може той факт, що на Пересопницькому Свангелії 1556 р. новообрані президенти присягають на вірність народу України), про сферу діловодства (близька до живої народної українська мова XIV - початку XVI ст. була офіційною діловою мовою Великого князівства Литовського, відома як «актова мова»), а також про ораторські твори, житійно-повістеву літературу, наукову сферу та ін. Увиразнять історико-лінгвістичні знання тексти Г. Сковороди, I. Котляревського, Т. Шевченка, І. Франка, Л. Українки тощо. Слід наголосити на винятковому значенні в історії розвитку української літературної мови І. Котляревського як зачинателя нової української мови та творчості Т. Шевченка, у якій закладені риси сучасної української літературної мови. Усе це сприятиме розширенню ерудиції культурологів, виробленню мовної стійкості, критичного ставлення до наявних у сучасній ситуації інформаційної війни фейкових «вкидів» щодо історичного розвитку української мови.

У підготовці культурологів важливо сформувати погляд на українську мову не лише як на суто теоретико-граматичний комплекс, а як на інтегровану систему, що вибудовувалася століттями у тісному взаємозв'язку з історією, фольклором, етнографією, літературою тощо. Важливим $є$ спонукати до усвідомлення змістового наповнення, з яким буде пов'язана майбутня діяльність здобувачів вищої освіти, окреслення кола їхніх професійних інтересів, ситуацій спілкування. Навчально-дидактичні міжпредметні зв'язки у межах навчальних матеріалів і посібників для культурологів повинні реалізуватися через залучення відомостей і текстів української літератури, історії, географії. У доборі навчального матеріалу слід враховувати ціннісно-професійні орієнтири, вдало поєднуючи професійний зміст і мовну організацію навчальних текстів, тематику завдань комунікативного характеру, продумувати можливі ситуації професійного спілкування. Саме тоді формування мовленнєвих умінь і навичок культурологів буде здійснюватися через реалізацію цікавих для них цільових професійних тем, мотивувати до вивчення української мови.

У навчанні української мови студентів-культурологів поруч із завданнями поглиблення українознавчих знань і навчання досконалого, нормативного володіння мовою стоїть потреба навчити комунікувати, використовувати мову з метою постановки і розв'язання професійних завдань. Соціокультурна компетенція $\epsilon$ сукупністю знань, умінь і здібностей особистості фахівця, які надають можливість спілкуватися українською мовою в різних професійних ситуаціях згідно з чинними мовленнєвими і поведінковими нормами, а також згідно з традиціями культури. Структура соціокультурної компетенції поєднує країнознавчу (здатність усвідомлювати знання про народ, культуру країни, факти державного устрою, історію, географію, економіку, літературу, мистецтво, особливості побуту, традицій, звичаїв тощо), лінгвокраїнознавчу (знання особливостей мовленнєвої і немовленнєвої поведінки у спілкуванні, інформованість про умови повсякденного життя, міжособистісні стосунки, суспільні цінності, соціальні умовності, виражені типовими формулами мовного етикету та позамовними засобами-жестами, соціальні звичаї) і соціолінгвістичну компетенцію (дотримання у мові відповідно до мети і ситуації спілкування правил ввічливості, міжперсональних стосунків між поколіннями, статями, соціальними групами).

Для досягнення означених вище завдань учені звертають увагу на можливості культурного навчального 
тексту, а отже, виникає потреба збагачення текстотеки з української мови за професійним спрямуванням текстами країнознавчої і краєзнавчої тематики. Краєзнавчий текст - «автентичний чи модельований текст на краєзнавчу тему, методично опрацьований (iз урахуванням рівня читацької компетентності цільової аудиторії) відповідно до мети навчання й конкретних завдань» (Швець, 2019). Принципи добору текстів і створення системи завдань до них спрямовані на розвиток мовних і мовленнєвих умінь (це суспільно-політичні тексти, тексти соціокультурної тематики, краєзнавчі, офіційно-ділові, тексти художньої літератури). Саме на основі аналізу і виокремлення актуальних для вивчення сфер спілкування здійснюється наповнення навчальної текстотеки - масиву різностильових та різножанрових текстів для навчання мови. Для підготовки культурологів ключовими є освітньо-наукова, професійна та суспільна сфери спілкування. Вимогами до добору навчальних текстів $\epsilon$ орієнтація на українознавчу інформацію, їі типовість, актуальність, стабільність, новизна, доступність, наочність.

Особливим є світоглядно-виховне значення українознавчих текстів, яке є провідним під час вивчення усіх розділів вишівського курсу мови за професійним спрямуванням і передбачає виховання національних почуттів, національної ідентичності, патріотизму, поваги до історичного минулого України, іiі культури, мови, формування світоглядних орієнтирів здобувачів вищої освіти як носіїв національних цінностей, усвідомлення ними своїх обов'язків як членів суспільства, відповідальних за майбутнє країни, засвоєння понять «національна мова», «літературна мова», «державна мова», «рідна мова», «національно-мовна картина світу», опрацювання на основі подібних текстів різних стилів і жанрів, встановлення у них національно маркованих, діалектних мовних одиниць та їхнього стилістичного навантаження, засвоєння етноетикету спілкування та використання норм самовираження у ситуаціях професійного спілкування, формування вмінь створювати власні національно-культурні тексти на основі здобутих знань.

Окреслюючи структуру й систему роботи на основі тексту у навчальних матеріалах та посібниках для культурологів, слід наголосити на їх лінгводидактичному потенціалі (історико-довідкові, наукові, науково-популярні, науково-публіцистичні тексти), їхніх лінгвостилістичних можливостях для засвоєння професійної лексики і термінології (Окуневич, Хоменко, 2011). Українознавчий дискурс складають жанрові різновиди текстів писемного та усного мовлення: наукова, краєзнавча словниково-довідкова стаття, науково-популярна стаття краєзнавчого характеру, науково-навчальний текст на краєзнавчу тематику, альбом, путівник, рекламний туристичний проспект, текст екскурсії, підпис музейного експоната, документальні фільми історичної тематики тощо. Основною функцією таких текстів $є$ фокусування уваги на фактологічному (культурознавчому, історичному, географічному, народознавчому, мистецтвознавчому) матеріалі та лексичних, стилістичних, граматико-стилістичних особливостях мови, завдяки яким реалізується понятійно-термінологічний компонент міжпредметних зв'язків.
Українознавчі тексти варто супроводжувати різноманітними видами завдань на їх основі (стандартні лексико-граматичні вправи і вправи стилістичного характеру), змістові вправи (дати відповіді на запитання, визначити тему і основну думку, визначити мікротеми, скласти план до тексту тощо), комунікативні вправи i завдання, пов'язані із продукуванням власного мовлення у типових ситуаціях професійного спілкування. Навчально-комунікативні вправи забезпечують запам'ятовування національно маркованих засобів мови, їх використання в різних типах і стилях мовлення (відшукати в текстах власне українські слова, на відміну від запозичень, дібрати українські відповідники до іншомовних слів і термінів; створити професійний словничок культуролога; пояснити значення діалектизмів, їх авторське стилістичне вживання, замінити їх літературними відповідниками; здійснити аналіз тексту з погляду вживання специфічних для української мови граматичних засобів, пояснити стилістичне навантаження слів із зменшено-пестливими суфіксами тощо), продуктивні вправи (запам ятати і пояснити висловлювання відомих українських діячів про національні цінності українського народу), репродуктивні вправи (простежити функціонування національно орієнтованих мовних елементів у текстах-зразках українознавчого змісту та відтворити чи перетворити їх із використанням означеного мовного матеріалу).

Культурологи, які працюють з історичною літературою, мають добре розуміти зміст історичної лексики (архаїзмів та історизмів), коментувати їі, замінювати архаїзми сучасними синонімами. До словника культурологів слід залучати українські лексеми, що вийшли з ужитку, але наявні у літературних творах попередніх епох: мапа (карта), кщталт (образ), хиби (помилки), штука (мистецтво), мент (момент), свічадо (підсвічник), люстерко (дзеркало) тощо, значення яких варто пояснити. Розвиваючи лексико-семантичний підхід до вивчення лексики, слід розвивати уміння вирізняти маловідомі слова у тексті та формувати потребу з'ясовувати їхнє значення за словниками.

На особливу увагу заслуговують фразеологізми та крилаті вислови народно-побутового, біблійного походження. Фольклорні тексти та тексти художньої літератури дають необхідний матеріал для лінгвістичних спостережень. Їх аналіз сприяє усвідомленню тісного зв'язку між словом і фразеологізмом чи крилатим висловом, з'ясуванню відмінностей між стійкими і вільними словосполученнями, допомагає розвитку пізнавальних здібностей (Окуневич, Хоменко, 2011). Реалізуючи міжпредметні зв'язки, можна пропонувати виписати фразеологічні одиниці з тексту, укласти фразеологічні словнички, пояснити їхне значення, засвоюючи стандартні вислови-фразеологізми ділового чи наукового професійного мовлення, навчитися вводити їх у контекст, доречно використовувати у спілкуванні.

Власне комунікативні вправи зорієнтовані на елементи творчості, конструювання різножанрових та різностильових висловлювань культурологічного змісту на запропоновану тему та редагування чужих висловлювань, моделювання ситуацій спілкування. Серед цих вправ можна означити такі: запропонувати заголовок до тексту; написати план і тези до тексту; створити власний 
текст або продовжити текст за початком, висловлюючи власну позицію щодо проблеми; дописати кінцівку; розширити або згорнути основну частину тексту; підготувати висновки щодо прочитаного чи почутого; на основі запропонованого словничка написати монологічне висловлювання на професійну тематику; створити діалог відповідно до професійної мовленнєвої ситуації; зредагувати текст, вилучаючи ненормативні елементи і збагачуючи його українськими лексемами та усталеними зворотами; описати предмет народного мистецтва за допомогою термінологічних лексичних засобів; скласти твір-мініатюру за прислів 'ям чи приказкою; створити тексти-екскурсії або наукові тексти-доповіді про національно-культурні персоналії тощо. Більшого ефекту у виконанні подібних завдань надає моделювання ситуації спілкування, уявлення про мовлення у певному місці чи у певному оточенні (лекція, доповідь, конференція, засідання “круглого столу”, екскурсія, культурно-виховний захід тощо), що сприяє зв'язку навчання мови з життям.

Висновки. Таким чином, урахування українознавчих засад відіграє важливу роль у підготовці фахівців-культурологів. В означеному контексті важливо зважати на аналіз сучасних концепцій мовної освіти, завданням яких $є$ розробити технологію формування національно свідомої україномовної особистості.

Формування етнокомунікативних умінь і навичок $\epsilon$ двостороннім процесом навчання і виховання студентів-культурологів, що передбачає розвиток мовної особистості засобами рідної мови та вироблення національного колориту мовлення. Залучення фактів 3 історії української мови, історичний коментар мовних явищ $\epsilon$ необхідним для формування мовної і мовленнєвої компетентності, україномовної культури, виховання історичної пам'яті та національної свідомості. Важливо враховувати регіональний лінгвокраєзнавчий компонент, що поглиблює зв'язок навчання із життям.

Українознавчий підхід викладання мови за професійним спрямуванням забезпечується принципом міжпредметності та текстоцентризму, що передбачає поліфункціональне застосування українознавчих текстів. У результаті їх змістового та мовного аналізу фахівці поглиблюють свої знання інформацією культурологічного змісту, збагачують своє мовлення спеціальними мовними засобами. Такий українознавчий текстовий матеріал повинен викликати бажання висловитися, викласти своє бачення інформації, вступити в дискусію, мотивувати до продукування власних висловлювань. Моделювання професійних комунікативних ситуацій сприяє набуттю досвіду мовленнєвої діяльності, готовності до ситуативного мовлення, успішної реалізації комунікативного наміру.

Таким чином, формування комунікативних умінь і навичок студентів-культурологів на українознавчих засадах спрямоване на більш глибоке оволодіння національно-культурним компонентом мови, збагачення словникового запасу студентів мовними одиницями. Отримані знання про цінності, культурні традиції українського народу дають можливість в подальшому створювати власні тексти культурологічного спрямування та їх редагувати.

Перспективи подальших досліджень. Окреслені напрямки роботи, апробовані у власній педагогічній діяльності, розвивають уміння послуговуватися мовними засобами нормативно та комунікативно-виправдано, розширюють кругозір, формують мовну стійкість, забезпечують формування більшості професійних компетентностей студентів-культурологів. Вивчення мови професійного спрямування з опорою на історичні, літературні, фольклорні тексти та реалізація у їх доборі міжпредметних зв'язків допомагає створити мотивацію у вивченні дисципліни та викликати інтерес до предмета, посилити установку на свідоме засвоєння навчального матеріалу. У зв'язку з цим подальшого аналізу потребують форми і способи уведення такої інформації з метою підвищення інтересу студентів до опанування курсу української мови за професійним спрямуванням та формування мовно-професійної вправності.

\section{СПИСОК ВИКОРИСТАНОЇ ЛІТЕРАТУРИ}

Виткалов, В. Г., Казначеєва, Л. К., Тюска, В. Б. (2019). Освітньо-професійна програма «Культурологія». Рівне: РДГУ. 19 с.

Пентилюк, М. I. (1987). Міжпредметні зв'язки на уроках мови. Украӥнська мова і література в школі. № 5. C. 41 .

Груба, Т. (1998). Засвоєння синонімічних форм на міжпредметній основі. Дивослово. № 7. С. 17-19.

Шляхова, В. В. (2009). Українознавчі засади мовної освіти: монографія. Київ: НДІУ. 118 с.

Стельмахович, М. Г. (1993). Етнопедагогічні основи методики української мови (перевидання). Дивослово. № 5-6. С. 19-23.

Пентилюк, М. І., Нікітіна, А. В., Горошкіна, О. М. (2004). Концепція когнітивної методики навчання української мови. Дивослово. № 8. С. 5-10.

Єрмоленко, С. (2001). Національна свідомість і виховання української мовної особистості. Урок української. № 11-12. С. 9-10.

Єрмоленко, С., Мацько, Л. (1994). Навчально-виховна концепція вивчення української (державної) мови. Дивослово. № 4. С. 28-33.

Біляєв, О., Скуратівський, Л., Симоненкова, Л., Шелехова, Т. (1996). Концепція навчання державної мови в школах України. Дивослово. № 1. С. 16-21.

Шевчук, С. В., Клименко, І. В. (2013). Українська мова за професійним спрямуванням: підручник. 3-тє вид., випр. і доп. Київ: Алерта. 696 с.

Культура фахового мовлення: навч. посіб. (2006) / за ред. Н. Д. Бабич. Чернівці: Книги - XXI. 296 с.

Мацюк, 3., Станкевич, Н. (2010). Українська мова професійного спілкування: навч. посіб. Київ: Каравела. $352 \mathrm{c}$.

Швець, Г. Д. (2019). Краєзнавчий текст у навчальній текстотеці з української мови як іноземної. Молодий вчений. № 6.1 (70.1). Червень. С. 69-74.

Окуневич, Т. Г., Хоменко, В. Б. (2011). Використання краєзнавчого матеріалу на уроках української мови. Педагогічні науки: збірник наукових праць. Т. 1. № 60. C. 129-133.

\section{REFERENCES}

Vytkalov, V. H., Kaznacheieva, L. K., Tiuska, V. B. (2019). Osvitno-profesiina prohrama [Kulturolohiia Educational and professional program «Culturology»]. Rivne: RDHU. 19 s. [Ukrainian]. 
Pentyliuk, M. I. (1987). Mizhpredmetni zviazky na urokakh movy [Cross-curricular links in language lessons]. Ukrainska mova i literatura v shkoli. № 5. S. 41. [in Ukrainian].

Hruba, T. (1998). Zasvoiennia synonimichnykh form na mizhpredmetnii osnovi [Assimilation of synonymous forms on an interdisciplinary basis]. Dyvoslovo. № 7. S. 17-19. [in Ukrainian].

Shliakhova, V. V. (2009). Ukrainoznavchi zasady movnoi osvity [Ukrainian studies principles of language education]: monohrafiia. Kyiv: NDIU. 118 s. [in Ukrainian].

Stelmakhovych, M. H. (1993). Etnopedahohichni osnovy metodyky ukrainskoi movy (perevydannia) [Ethnopedagogical bases of Ukrainian language methodology (reprint)]. Dyvoslovo. № 5-6. S. 19-23. [in Ukrainian].

Pentyliuk, M. I., Nikitina, A. V., Horoshkina, O. M. (2004). Kontseptsiia kohnityvnoi metodyky navchannia ukrainskoi movy [The concept of cognitive methodology of Ukrainian language teaching]. Dyvoslovo. № 8. S. 5-10. [in Ukrainian].

Yermolenko, S. (2001). Natsionalna svidomist i vykhovannia ukrainskoi movnoi osobystosti [National consciousness and education of the Ukrainian language personality]. Urok ukrainskoi. № 11-12. S. 9-10. [in Ukrainian].

Yermolenko, S., Matsko, L. (1994). Navchalno-vykhovna kontseptsiia vyvchennia ukrainskoi (derzhavnoi) movy [Educational concept of studying the Ukrainian (state) language]. Dyvoslovo. № 4. S. 28-33. [in Ukrainian].
Biliaiev, O., Skurativskyi, L., Symonenkova, L., Shelekhova, T. (1996). Kontseptsiia navchannia derzhavnoi movy v shkolakh Ukrainy [Concept of teaching the state language in schools of Ukraine]. Dyvoslovo. № 1. S.16-21. [in Ukrainian].

Shevchuk, S. V., Klymenko, I. V. (2013). Ukrainska mova za profesiinym spriamuvanniam [Ukrainian language for professional purposes]: pidruchnyk. 3-tie vyd., vypr. i dop. Kyiv: Alerta. 696 s. [in Ukrainian].

Kultura fakhovoho movlennia [The culture of professional speech]: navch. posib. (2006) / za red. N. D. Babych. Chernivtsi: Knyhy - XXI. 296 s. [in Ukrainian].

Matsiuk, Z., Stankevych, N. (2010). Ukrainska mova profesiinoho spilkuvannia [in Ukrainian language of professional communication]: navch. posib. Kyiv: Karavela. 352 s. [in Ukrainian].

Shvets, H. D. (2019). Kraieznavchyi tekst u navchalnii tekstotetsi z ukrainskoi movy yak inozemnoi [Local lore text in the educational text library of Ukrainian as a foreign language]. Molodyi vchenyi. № 6.1 (70.1). Cherven. S. 69-74. [in Ukrainian].

Okunevych, T. H., Khomenko, V. B. (2011). Vykorystannia kraieznavchoho materialu na urokakh ukrainskoi movy [Use of local history material in Ukrainian language lessons]. Pedahohichni nauky: zbirnyk naukovykh prats. T. 1. № 60. S. 129-133. [in Ukrainian].

Дата надходження до редакиіï: 04.10.2021 p. 